\title{
チェダーチーズの粘弾性試験法に基づいた 食感評価モデルの開発
}

\author{
守田愛梨 ${ }^{1, \dagger}$ ，荒木徹也 ${ }^{1}$, 池上翔馬 ${ }^{2}$, 岳上美紗子 ${ }^{3}$, \\ 住 正宏 $^{3}$, 上田玲子 ${ }^{4}$, 相良泰行 ${ }^{4}$ \\ 1 東京大学大学院農学生命科学研究科, ${ }^{2}$ 森永乳業株式会社食品総合研究所, \\ 3 森永乳業株式会社応用技術センター, ${ }^{4}$ 一般社団法人 食感性コミュニケーションズ
}

\section{Development of Texture Evaluation Model Based on Viscoelastic Testing Methods for Cheddar Cheese}

\author{
Airi MORITA ${ }^{1, \dagger}$, Tetsuya ARAKI ${ }^{1}$, Shoma IKEGAMI ${ }^{2}$, Misako OKAUE ${ }^{3}$, \\ Masahiro SUMI ${ }^{3}$, Reiko UEDA ${ }^{4}$, Yasuyuki SAGARA ${ }^{4}$ \\ ${ }^{1}$ Department of Global Agricultural Sciences, Graduate School of Agricultural and Life Sciences, The University of Tokyo, \\ 1-1-1, Yayoi, Bunkyo Ward, Tokyo 113-8657, Japan \\ ${ }^{2}$ Food Science and Technology Institute, Morinaga Milk Industry, Co., Ltd., \\ 5-1-83, Higashihara, Zama, Kanagawa 252-8583, Japan \\ ${ }^{3}$ Product Evaluation Center, Morinaga Milk Industry, Co., Ltd, 5-1-83, Higashihara, Zama, Kanagawa, 252-8583, Japan \\ ${ }^{4}$ Food Kansei Communications, Corp., Toa-mansion No.103, 4-24-7, Sendagi, Bunkyo Ward, Tokyo 113-0022, Japan
}

\begin{abstract}
Novel methodologies have been developed to predict the values of sensory evaluation score by selecting the combination of measurement methods for grouping viscoelastic parameters, and coupled PLS and ANN modeling have been presented as a quality evaluation model based on the relationship analysis between viscoelastic parameters and sensory scores for Cheddar cheese. Ten Cheddar cheeses were selected as test samples and viscoelastic characteristics of the samples were obtained by three measurement methods of fracture, creep and texture tests. Thirty-eight sensory terms including 10 terms of texture attribute were selected and then sensory evaluation using the terms as well as consumer palatability test were conducted for collecting both sensory and palatability scores, respectively. The relationships between viscoelastic parameters and texture changes in human mouth were explainable by adapting the relationships between the viscoelastic characteristics and texture in the mastication process of the force vs. time curve obtained from the two bites process of the sample, and thus selection manner for the combinations of viscoelastic measurement methods corresponding to sensory texture scores were demonstrated by comparing the accuracy of PLS regression equations. Furthermore, ANN models to predict sensory texture and palatability scores were successfully presented by applying each viscoelastic parameter obtained by the selected combinations of the measurement methods. By the modeling process proposed in this study, ANN models were operational to utilize the optimal viscoelastic measurement methods contributing to the sensory and palatability scores.
\end{abstract}

Keywords: viscoelastic parameter, texture, sensory evaluation, PLS, ANN modeling

1. 緒

言

食感とは，食品が人の口腔内に打いて咀嚼や舌によ る唾液との混合などの影響を受けて状態変化したもの,

(受付 2015 年 1 月 26 日, 受理 2015 年 5 月 25 日)

1 个113-8657 東京都文京区弥生 1-1-1

2 于 $252-8583$ 神奈川県座間市東原 5-1-83

3 于 252-8583 神奈川県座間市東原 5-1-83

4 个113-0022 東京都文京区千駄木 4-24-7 トーアマンション 103

$\dagger$ Fax: 03-5841-5335, E-mail: ailymorita@gmail.com
あるいはその変化の過程を知覚することによって生じ る物理的刺激に由来する感覚である [1]，チーズの食感 は，消費者の感じる打いしさ評価に重要な因子である ことが知られている $[2-5]$ ，そのため，チーズの食感を コントロールすることは，チーズの品質制御に打ける 主要因の 1 つであるといえる.

チーズの食感がその品質評価に大きな影響を与える 因子であることから，物理的な計測によって得た粘弾 性特性と官能評価スコアとの相互関連性について，多 
くの先行研究がなされている [6-9]. とくに，主成分分 析やPLS といった多変量解析手法を使用して, 粘弾性 特性と官能評価スコアを関連付ける報告が数多い [10$14]$.

測定機器によってチーズの食感を計測する手法とし て，一般的には破断試験，クリープ試験打よびテクス チャ試験が行われている，チーズの粘弾性計測項目の 中で, 最も計測目標とされることの多い粘弾性特性は, 硬さもしくはその硬度である [15]。しかし，チーズの 食感であるとして計測している粘弾性特性の定義やそ の測定条件が報告者によって異なるため，必ずしも一 般性をもつ測定結果が得られているとは限らない。ま た，チーズの粘弾性特性については，レオロジーの理 論に基づいて研究した報告例は少ないために，チーズ の粘弾性特性と官能評価スコアとの相互関連性は系統 的に把握されていない，先のため，両者の対応関係を 粘弾性特性の計測原理に基づいてモデリングし，この モデルによって人のおいしさ評価に影響を及ぼす食感 を粘弾性特性の值によって定量的に評価することがで きない現状にある。

本研究の目的は，チェダーチーズの粘弾性計測パラ メータと官能評価スコアの相互関係解析に基づいて, 1) 高精度で官能評価スコアを予測する機器試験法の組み 合わせを選択する方法を開発し，2）その組み合わせを 用いてPLS とANNを併用した食感評価モデルを提唱 することにある。

\section{2. 供試サンプルと実験方法}

\section{1 供試サンプル}

チェダーチーズの標準的な粘弾性特性に基づいて品 質評価モデルを構築するためには，市販用とプロセス チーズ原料用の両方から化学組成が均一な試料を供試
サンプルとする必要があると考えた。このため供試サ ンプルとして，市販用チェダーチーズ（No.3，9，10) 打よびプロセス原料用（No.1，2，4，5，6，7，8）の 10 品を選んだ．Table 1 にそれらの製造地域，製造年月 日打よび熟成期間を示す．また， Table 2 にこれらのサ ンプルの化学組成の質量パーセント濃度, ミネラル分, 遊離アミノ酸, 遊離脂肪酸, 有機酸などの総含有量お よび $\mathrm{pH}$ を示した．供試サンプルの水分，脂肪および蛋 白質の計量分析にはそれぞれ常圧加熱乾燥，酸アンモ ニア分解法打よび modified Dumas 法を用いた。また， 灰分量は五訂日本食品標準成分表分析マニュアルに 則って分析し, 炭水化物量は化学組成の質量パーセン 卜濃度の $100 \%$ から水分, 脂肪, 蛋白質および死分の割 合を除することによって求めた。食塩量はVolhard 法 を用いて分析し, $\mathrm{pH}$ の計測は粉砕した供試サンプルに pH 電極（9625-10D probe, pH meter D-51T, HORIBA Ltd., Kyoto, japan）を直接突き刺して行った. さらに, 遊離アミノ酸，遊離脂肪酸打よびミネラルの分析には それぞれニンヒドリンポストカラム発色法 (L-8900, No.2623PF, HITACHI High Technologies Co., Japan), ガスクロマトグラフィー法 (GC6890, Agilent

Table 1 Data of the test samples.

\begin{tabular}{clcc}
\hline No. & $\begin{array}{c}\text { Area of } \\
\text { Production }\end{array}$ & $\begin{array}{c}\text { Date of } \\
\text { Manufacture }\end{array}$ & $\begin{array}{c}\text { Aging } \\
\text { period }^{* *}\end{array}$ \\
\hline 1 & Oceania & 2010.11 .24 & 5 \\
2 & USA & 2011.03 .17 & 2 \\
3 & Japan & 2011.07 .20 & 4 \\
4 & Oceania & 2010.12 .10 & 6 \\
5 & Oceania & 2011.02 .07 & 4 \\
6 & Oceania & 2012.03 .05 & 0 \\
7 & USA & 2011.11 .17 & - \\
8 & Oceania & $2011.01 .-^{*}$ & 5 \\
9 & Japan & - & - \\
10 & Europe & 2012.03 .27 & 5 \\
\hline
\end{tabular}

*; Date was unknown, ${ }^{* *}$ Unit ; month

Table 2 Chemical compositions of the samples.

\begin{tabular}{|c|c|c|c|c|c|c|c|c|c|c|}
\hline \multirow[b]{4}{*}{ Samples } & \multicolumn{9}{|c|}{ Chemical compositions } & \multirow{4}{*}{$\mathrm{pH}$} \\
\hline & \multirow[b]{3}{*}{ Fat } & \multirow[b]{3}{*}{ Protain } & \multicolumn{3}{|l|}{ (Unit: wt\%) } & \multirow{2}{*}{\multicolumn{4}{|c|}{$\frac{\text { (Unit: } \mathrm{mg} / 100 \mathrm{~g} \text { ) }}{\text { Total }}$}} & \\
\hline & & & \multirow[b]{2}{*}{ Carbohydrate } & \multirow[b]{2}{*}{ Ash } & \multirow[b]{2}{*}{ Moisture } & & & & & \\
\hline & & & & & & minerals & $\begin{array}{l}\text { Free } \\
\text { amino } \\
\text { acids }\end{array}$ & $\begin{array}{c}\text { Free } \\
\text { fatty acids }\end{array}$ & $\begin{array}{c}\text { Organic } \\
\text { acids }\end{array}$ & \\
\hline No.1 & 34.8 & 24.0 & 0.9 & 4.0 & 36.3 & 3094.7 & 715.3 & 68.6 & 1422 & 5.3 \\
\hline No.2 & 33.4 & 24.1 & 1.7 & 3.6 & 37.2 & 2991.4 & 668.6 & 48.6 & 1397 & 5.2 \\
\hline No.3 & 34.6 & 25.5 & 1.5 & 4.1 & 34.3 & 3245.7 & 4269.4 & 176.6 & 1551 & 5.3 \\
\hline No.4 & 37.1 & 23.3 & 1.3 & 3.8 & 34.5 & 3103.9 & 2219.0 & 71.4 & 1306 & 5.4 \\
\hline No.5 & 37.4 & 23.5 & 0.8 & 3.8 & 34.5 & 3180.5 & 3715.1 & 89.5 & 1409 & 5.2 \\
\hline No. 6 & 34.9 & 26.4 & 4.2 & 1.8 & 32.7 & 33526 & 1005.7 & 132.4 & 929 & 5.5 \\
\hline No.7 & 38.0 & 24.9 & 3.7 & 0.3 & 33.1 & 2930.7 & 1698.1 & 64.7 & 1557 & 5.3 \\
\hline No.8 & 31.0 & 36.2 & 4.0 & 0.9 & 37.9 & 3024.8 & 1160.5 & 84.1 & 1429 & 5.4 \\
\hline No.9 & 32.4 & 24.8 & 3.7 & 2.3 & 36.8 & 2811.7 & 1116.8 & 78.9 & 1612 & 5.1 \\
\hline No.10 & 34.7 & 24.4 & 3.6 & 1.3 & 36.0 & 2846.6 & 1002.4 & 116.2 & 1456 & 5.0 \\
\hline
\end{tabular}


Technologies Inc., Palo Alto, Calif., U.S.A.) および ICP 発光分光分析法 (ICP-9000, shimadzu Co., Kyoto, Japan）を用いた。

供試サンプルは，まず約 $20 \mathrm{~kg}$ のチーズ塊から $200 \mathrm{~g}$ 程度のチーズブロックを複数個切り出し，次に，それ らの含水量と品温の変化による物性值変動を低減させ るためにラップで覆い $5{ }^{\circ} \mathrm{C}$ の恒温庫に 15 分以上保存し て試験に供した。粘弾性計測試験用サンプル試片は, 金属製のくり抜き器を用いて $10 \mathrm{~mm} \phi \times 10 \mathrm{~mm}$ の円柱 形に成形し，官能評価用には $15 \mathrm{~mm}$ のサイコロ状に切 り出して成形し，それぞれの試験に供試した。

\section{2 粘弾性試験装置と設定条件}

供試サンプルの破断，クリープおよびテクスチャ試 験に用いた試験装置（山電製クリープメータ， RE233005 s 型）の構成図を Fig. 1 に示す。この装置は粘弾 性計測部，試料厚さ計，データ収録装置および制御用 パーソナルコンピュータより構成されている．計測部 では，試料台が一定速度で昇降して試料を压縮すると 同時に，プランジャ上部のロードセルによって荷重の 経時変化を検出する機構となっている. 円柱型プラン ジャの直径と圧縮速度は，載荷開始直後から終了時ま での荷重と歪みの経時変化を記録できる条件を予備実 験により確認し，圧縮後のサンプル直径よりも大きい $55 \mathrm{~mm} \phi$ と $0.5 \mathrm{~mm} / \mathrm{s}$ をそれぞれ選択した。 また，破断 およびテクスチャ試験に必要な最大荷重は $200 \mathrm{~N}$ 以下 であることを確認し，これらの試験には最大荷重 $200 \mathrm{~N}$ のロードセルを用い，試験装置のクリアランスを $5 \mathrm{~mm}$ に設定した。クリープ試験では荷重一歪率曲線の初期 に観察される線形性が保たれている範囲の載荷条件を 用いて最大荷重を設定する必要があるため [16]，この 条件を満たす載荷条件は最大荷重 $3 \mathrm{~N}$, 歪率 $10 \%$ であ ることを確認して最大荷重 $20 \mathrm{~N}$ のロードセルを選択し て用いた。また，クリープ試験の測定時間は 100 秒間 とした。これらすべての試験法の測定誤差を評価する ために，それぞれの試験は同一サンプルにつき 3 回以 上繰り返し測定した。これらの試験法には，測定曲線 から粘弾性パラメータを推算する解析ソフトが提供さ れている. 次項以下にこれらの推算法について述べる.

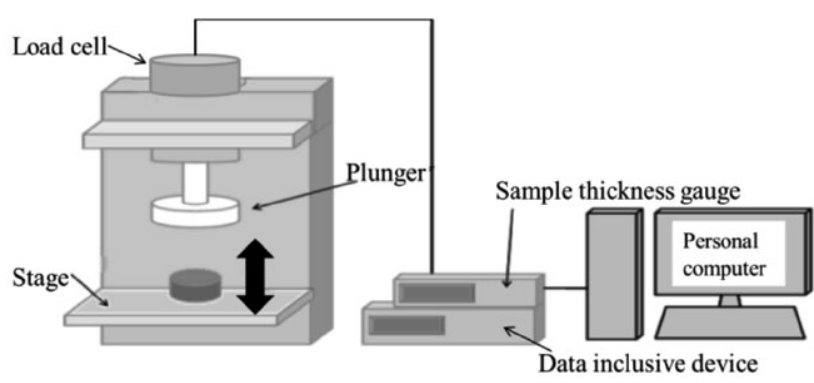

Fig. 1 Schematic of viscoelastic measurement equipment.

\section{3 解析モデルによるパラメータの推算法 2.3.1 破断試験}

チェダーチーズを対象として得られる典型的荷重一 歪率曲線を Fig. 2 に示す.この曲線から推算されるパ ラメータは曲線の変曲点から得られる破断荷重 (braking force) [N], 破断歪率 (braking rate) [\%], 最大荷重（Maximum force）[N] およびX軸と破断点 に至る曲線で囲まれる面積から推算される破断エネル ギー (energy of fracture) $\left[\mathrm{J} / \mathrm{m}^{2}\right]$ である，ここで，供 試サンプルの変形挙動を歪率の変化から分析するため に，その挙動特性を 4 段階（I～IV) に分けて Fig. 2 に示す.

この曲線の初期段階 I （歪率：0〜 5\%）は，試片と プランジャの表面接触角度のズレやサンプル表面の微 細な凹凸との部分的接触の影響を受けていると考えら れた。比例段階 II （歪率：5〜10\%）の曲線 b-c は直線 近似できることから，試片は弾性的挙動を示すと考え られる。したがって，この段階の近似直線の荷重範囲 からクリープ試験に必要な載荷荷重を算出することが 可能である．構造変形段階 III（歪率：10～50\%）では， 試片が圧縮されて破断点 $\mathrm{d}$ に至る挙動を示す。曲線 $\mathrm{d}-\mathrm{f}$ で示される圧密段階 IV（歪率：50～95\%) では，破断 点 $\mathrm{d}$ から次の変曲点 $\mathrm{e}$ を経て, 最大荷重点 $\mathrm{f}$ に至る挙 動を示し，破断されたチーズの圧縮がさらに進み，そ の圧密速度は変曲点 $\mathrm{e}$ 前後で急激に変化することを示 している.

\subsection{2 クリープ試験}

クリープ測定曲線（Fig. 3(a)）を4要素マックスウェ ル・フォークトモデル (Fig. 3(b)) で近似して得られる 粘弾性パラメータは, 瞬間弾性率 $E_{0}[\mathrm{~Pa}]$, 遅延弾性率 $E_{1}[\mathrm{~Pa}]$ ，遅延粘性率 $\eta_{1}[\mathrm{~Pa} \cdot \mathrm{S}]$ および 永久粘性率 $\eta_{\mathrm{N}}$ $[\mathrm{Pa} \cdot \mathrm{S}]$ である [17]. これらのパラメータを用いてクリー プ測定曲線は次式 (1)のように表わすことができる.

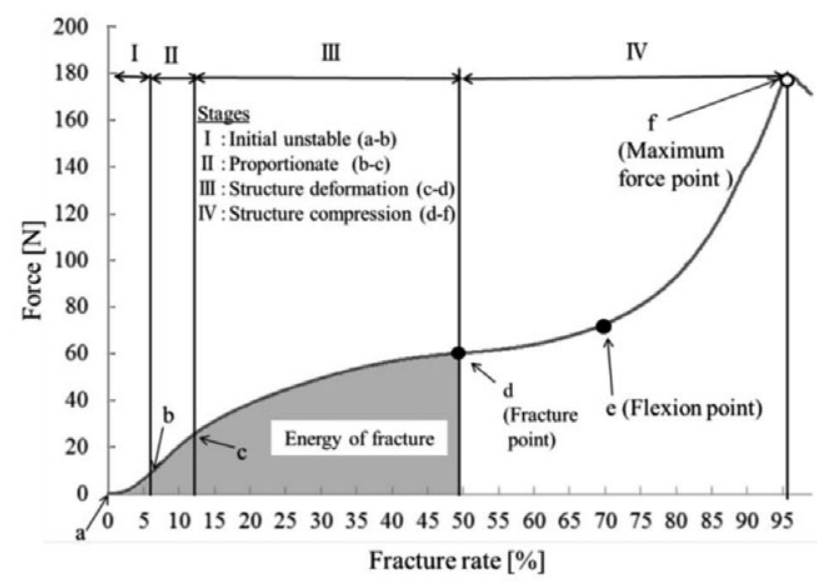

Fig. 2 Typical stages of sample fracture obtained from forcefracture rate curve. 


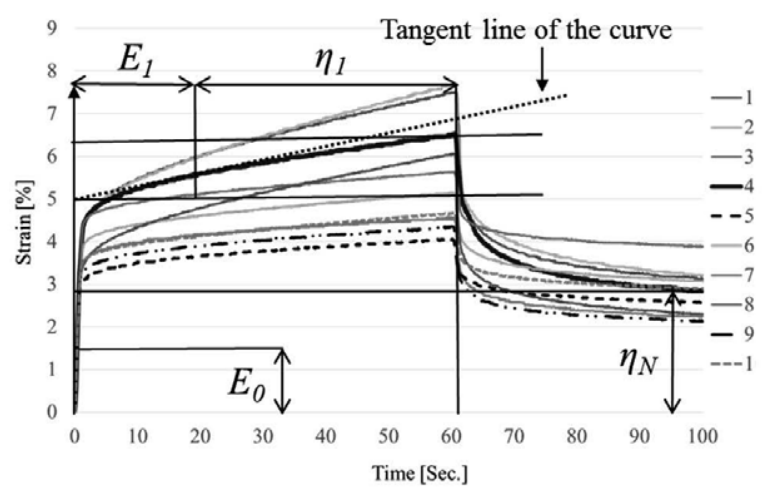

(a) Creep curve

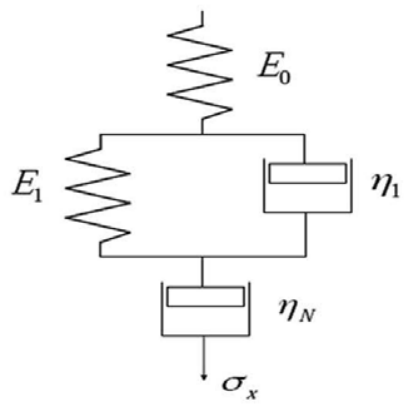

(b) Maxwell and Voigt model

Fig. 3 Creep curve and parameter estimation model.

$$
\varepsilon=\sigma_{\mathrm{x}}\left(\frac{1}{E_{0}}+\frac{1}{E_{1}}\left(1--\exp \left(-\frac{E_{1}}{\eta_{1}}\right)+\frac{1}{\eta_{N}} t\right)\right)
$$

ここで $\varepsilon, \sigma x$ 打よび $t$ はそれぞれ歪，載荷時の応力お よび時間を示す。また，その推算例として，供試サン プル No.4に対応する粘弾性パラメータを Fig. 3 (a) に 示す.

\subsection{3 テクスチャ試験}

サンプル試片を 2 バイト圧縮することにより得られ る荷重 - 移動距離曲線すなわちテクスチャプロファイ ル曲線（Fig. 4）から推算されるパラメータは，1バイ 卜目の最大荷重 (maximum force of texture test) [N] およびそれを供試サンプルの「かたさ」を示す指標と したかたさ荷重（hardness force）[N]，供試サンプル とプランジャの接触面の単位面積当たりの「かたさ」 指標を示すかたさ応力 (hardness) $\left[\mathrm{N} / \mathrm{m}^{2}\right]$ ， ガム性荷 重 (gumminess force) [N], ガム性応力 (gumminess) $\left[\mathrm{N} / \mathrm{m}^{2}\right], \mathrm{A} 1$ エネルギー (energy of A1) $\left[\mathrm{J} / \mathrm{m}^{3}\right], \mathrm{A} 2$ エ ネルギー (energy of A2) $\left[\mathrm{J} / \mathrm{m}^{3}\right]$, 凝集性 (cohesiveness) [-] および付着性 (adhesiveness) [ $\left.\mathrm{J} / \mathrm{m}^{3}\right]$ である.

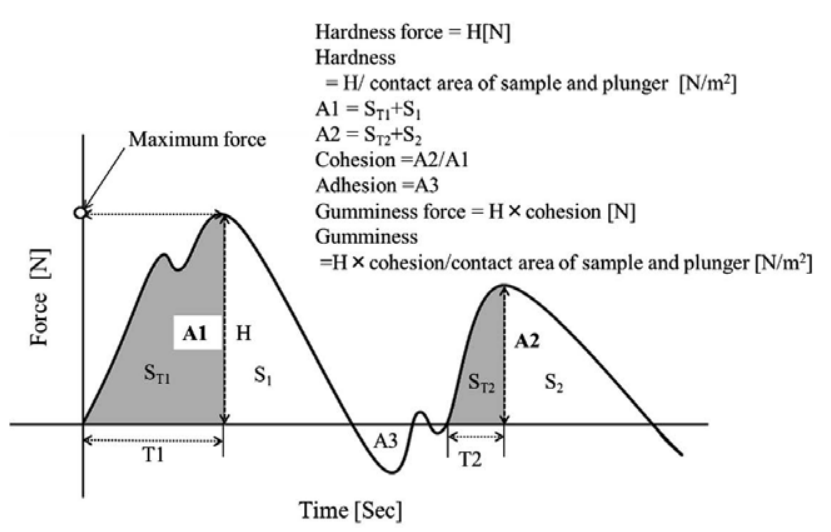

Fig. 4 Texture profile and estimation parameters.

\section{4 分析型官能評価法}

実際の官能評価に使用する実用用語を選定するため に，先ず ISO11035:19[18] および ISO22935-2/IDF992[19] に推奨された手順に従ってチェダーチーズの評価 に関する 106 語の収集用語を得た。次に 13 名の分析型 パネル候補者（男性 10 名，女性 3 名，30～50 代）によ る収集用語を使用した予備官能評価により，実用用語 を選択した。この評価は 15 センチ線尺度法を用いて繰 り返し 3 回行い，得られた評価スコアに対して相関分 析と分散分析を適用して用語間の類似度と認知度を算 出した。さらに選定した実用用語について分析型パネ ルによる定義共有化作業を行い, 最終的に外観属性 6 語, 香り，風味，味を含む香味属性 22 語および食感属性 10 語からなる 38 語を選定した. その結果得られたチェダー チーズの評価属性と実用用語のキーワードを Table 3 に 示す.

実用用語 38 語による官能評価は 10 名の分析型パネ ル（男性 9 名，女性 1 名）を用い，供試サンプルの提 示順をランダム化し，両端を固定した 0 から $15 \mathrm{~cm} の$ 線尺度法により実施した。この評価は官能評価室内に

Table 3 Sensory attributes and terms.

\begin{tabular}{llll}
\hline \multicolumn{4}{c}{ Sensory attributes } \\
\hline Appearance & \multicolumn{1}{c}{ Flavor (Odor, flavor \& taste) } & \multicolumn{1}{c}{ Texture } \\
\hline Terms (6) & \multicolumn{2}{c}{ Terms (22) } & Terms (10) \\
\hline Yellow & Friuty & Heating & Hardness \\
White & Yogurt & Lactic acid & Elasticity \\
Dry & Milky & Acetic acid & Crispness \\
Gas hole & Butyric acid & Diacetyl & Graininess \\
Crack & Soy sauce & Sweetness & Paste-like \\
Stone & Bread-like yeasty & Saltiness & Smoothness \\
& Alcoholic yeasty & Bitterness & Stickiness \\
& Vegemite-like yeasty & Astringency & Meltability \\
& Nuts & Harsh taste & Roughness \\
& Mushroom & Umami & Dried \\
& Potato-like & Sourness & texture \\
\hline
\end{tabular}

Total sensory terms: 38 
設けたパネル用ブースの白い机の上にサンプルを供試 して室温打よび䖝光灯条件下で実施し，同一サンプル を対象にして 3 回の繰り返しセッションを行った.また, それぞれのセッション毎に口腔内を洗浄するために, 紙コップ内の洗浄水をパネルに供給した。 パネルには, フィンガーテスト，匂い嗅ぎ扔よびサンプルを嚥下し て評価することを許可した。

\section{5 消費者の嗜好度調査法}

消費者の嗜好度，つまり「おいしさ」評価は，日本 の一般的な家庭に打いてチーズ製品の購入機会が多い と考えられる 30～50 代の主婦 59 名をパネルに選定し て実施した。このパネルの選定にあたっては，事前ア ンケートにより調査目的とは極端に異なる食嗜好を有 するパネルを除外した。また，実際の調查は分析型パ ネルと同様の環境下に打いて実施し，へドニック法に よる 9 点尺度法で評価した。

\section{6 統計解析法および ANN モデリング}

粘弾性パラメータ打よび官能評価スコアのデータ セットを対象にして，市販されている統計解析ソフト JMP10.0 Pro（SAS Inst., co., Cary, N.C., U.S.A）を適 用して, 主成分分析, PLS 回帰分析 (Partial Least Square regression) およびニューラルネットワーク (ANN) モデリングを行った.

主成分分析では，これらのデータセット間の相互関 係を分析するために，カイザー基準の固有值が 1.0 以上 を示す主成分についてヴァリマックス回転を適用し， データセットが顕著に分類される主成分数を求めた.

PLS 回帰分析では, 説明変数に粘弾性パラメータ, 目的変数に官能評価スコア打よび嗜好度を用い，元れ らの目的変数を精度良く説明できるパラメータの組み 合わせを探索した，得られたモデルの目的変数の予測 精度は重相関係数 $\left(\mathrm{R}^{2}\right)$ で評価した。 また，説明変数 の選択とそれらの目的変数に対する寄与度が必要な場 合にはステップワイズ PLS-VIP (Variable importance in projection) 法を適用し, VIP 值とモデル係数（Weight of model；W）を閾值として用いた。この方法により特 定された変数とその寄与度は, ANN モデリングに扔け る入力データとして用いた。

Fig. 5 に 3 層の知覚ネットワークからなる ANN モデ ルの構造を示す．この ANN モデルは入力層 $\left(\mathrm{X}_{1}, \mathrm{X}_{2}, \cdots\right.$, $\left.\mathrm{X}_{\mathrm{i}}\right)$ と出力層 $\left(\mathrm{Y}_{1}, \mathrm{Y}_{2}, \cdots, \mathrm{Y}_{\mathrm{k}}\right)$ およびその間のノード 数 3 の隠れ層 $\left(Z_{1}, Z_{2}, \cdots, Z \mathrm{j}\right)$ により構成される.こ のモデルの入力層に粘弾性パラメータ, 出力層に官能 評価スコアおよび嗼好度を適用し，それらの間の相互 関係を解析するモデルを構築した，モデリングの過程 では，最大学習回数打よびそのッアー数をそれぞれ 100 回と設定した。また，構築したモデルが学習モデルに
過剩フィットすることを防止するためにオーバー フィットペナルティ打よび収束基準をそれ兮れ 0.001 打 よび 0.00001 に設定し, 構築したモデルの予測精度を 評価する指標として $\mathrm{R}^{2}$ 打よび二乗平均平方根誤差 （RMSE）を用いた。

\section{3. 結果および考察}

\section{1 粘弾性計測}

3.1.1

サンプル試片の破断試験で得られた荷重一歪率曲線 をFig. 6 に示す.これらの測定曲線の挙動はサンプル No.6を除いて類似した傾向を示すことが確認された. いずれのサンプルでも試片の圧縮とともにその中央部 が徐々に膨らみ，その表面に亀裂が生じ，測定曲線上 に破断点に相当する変曲点を示した. 破断点通過後も 圧縮を継続し最大荷重点に到達すると，試片が薄い円 柱平板状に変形して側面の割れが観測された。また除 重した試片の表面に放射状の亀裂が生じていることが わかった. 破断点の最小值はサンプル No.5 の荷重 34.6 $\mathrm{N}$, 歪率 $20.8 \%$ であり, 最大值はNo.6の $104.2 \mathrm{~N}$, $61.4 \%$ であった。 また最大荷重点の荷重と歪率は，サン プル No.2の 103 N，93.8\%〜No.6の 191.6 N，93.3\%の

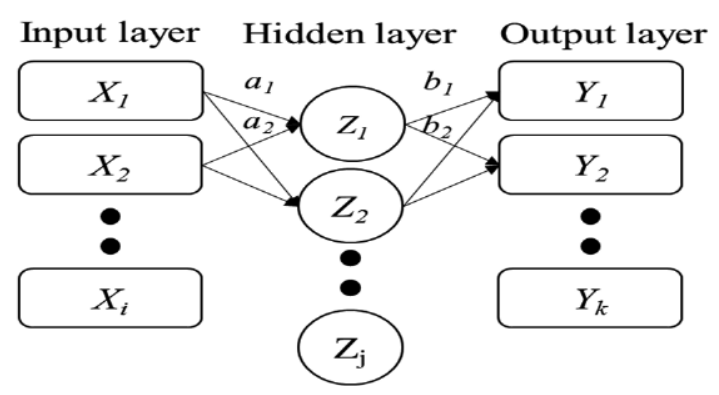

Fig. 5 An example of a 3-layer artificial neural network.

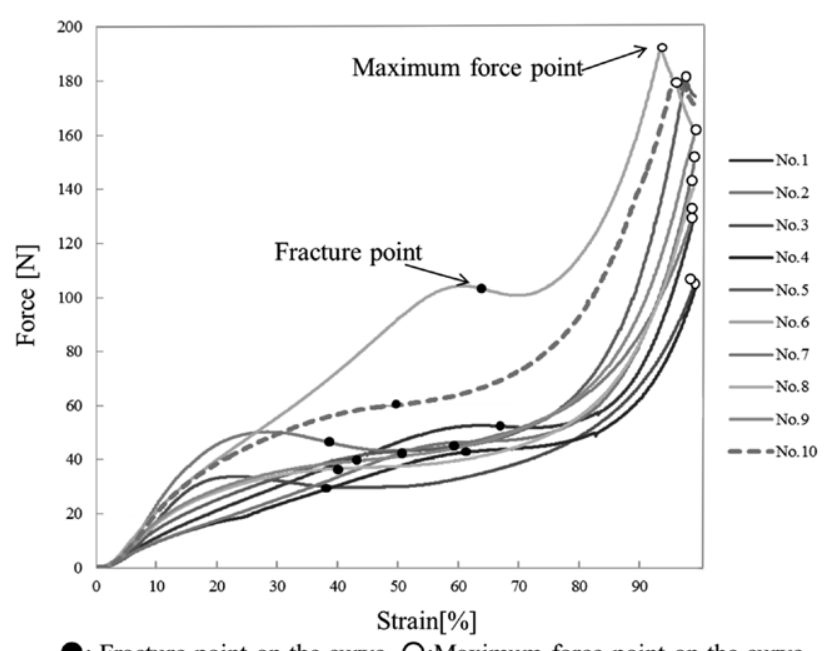

: Fracture point on the curve. O:Maximum force point on the curve.

Fig. 6 Force- fracture rate curve of samples. 
範囲にあった．特に，サンプル No.6 は他のサンプルと 比較して顕著に高い破断点と最大荷重点を示し，固い 食感を有することがわかった。これらの曲線の傾向か ら，供試サンプルは歪率 $20.8 \sim 61.4 \%$ の範囲内で破断点 を示し, 歪率約 $90 \%$ 以上で最大荷重を示すことがわかっ た.

\subsection{2 粘弾性特性の主成分分析}

粘弾性計測試験で得た粘弾性パラメータ 17 項目を, それらの類似性によって分類するために主成分分析を 適用した。 その結果，Table 4 に示すようにパラメータ は 3 つの主成分に分類でき，元の累積寄与率は $89.8 \%$ であった．粘弾性（Viscoelasticity）パラメータの主成 分を一般的主成分の表記（PC）と区別するために VPC と表記した。

VPC1 にはテクスチャとクリープ試験のパラメータが 区分された (寄与率 $60.5 \%$ )。VPC2 と VPC3には，そ れぞれ破断試験のパラメータとテクスチャ試験の付着 性が区分され，その寄与率は $20.4 \%$ と $8.8 \%$ であった。 これらの結果から, 粘弾性パラメータ 17 項目は, 破断 試験のパラメータとその他の試験のパラメータに大別 されることがわかった.

供試サンプルの粘弾性特性を明らかにするために, Fig. 7 にVPC1 と VPC2 に分類された供試サンプルの主 成分得点によるポジショニングマップを示した．図中の 円内に含まれる 9 サンプルの特徴は，VPC1に含まれる テクスチャとクリープ試験のパラメータ（寄与率 $60.5 \%$ ) と VPC2 の破断試験パラメータの主成分得点（寄与率 20.4\%）によって説明されることがわかった．他方，円

Table 4 Three viscoelastic principal components of the samples.

\begin{tabular}{lcrrr}
\hline \multicolumn{1}{c}{ Viscoelastic parameters } & \multicolumn{2}{c}{ Test } \\
method & VPC1 & VPC2 & VPC3 \\
\hline Maximum force of texture test & $\mathrm{T}$ & 0.99 & -0.03 & 0.02 \\
hardness force & $\mathrm{T}$ & 0.99 & -0.03 & 0.02 \\
hardness & $\mathrm{T}$ & 0.99 & -0.03 & 0.02 \\
energy of A1 & $\mathrm{T}$ & 0.99 & 0.02 & 0.09 \\
gumminess force & $\mathrm{T}$ & 0.98 & 0.05 & 0.08 \\
gumminess & $\mathrm{T}$ & 0.98 & 0.05 & 0.08 \\
energy of A2 & $\mathrm{T}$ & 0.97 & 0.11 & 0.16 \\
viscosity $\eta N$ & $\mathrm{C}$ & 0.96 & -0.03 & 0.09 \\
viscosity $\eta_{1}$ & $\mathrm{C}$ & 0.85 & 0.09 & 0.39 \\
elasticity $E_{1}$ & $\mathrm{C}$ & 0.83 & 0.00 & 0.47 \\
elasticity $E_{0}$ & $\mathrm{C}$ & 0.63 & 0.02 & -0.14 \\
cohesiveness & $\mathrm{T}$ & -0.60 & 0.48 & 0.36 \\
\hline energy of fracture & $\mathrm{F}$ & 0.04 & 0.99 & 0.01 \\
breaking force & $\mathrm{F}$ & 0.29 & 0.91 & -0.10 \\
maximum force & $\mathrm{F}$ & 0.11 & 0.85 & 0.12 \\
breaking rate & $\mathrm{F}$ & -0.53 & 0.83 & 0.03 \\
\hline adhesiveness & $\mathrm{T}$ & 0.16 & 0.04 & 0.95 \\
\hline \multicolumn{1}{c}{ Variance } & & 10.28 & 3.47 & 1.50 \\
\multicolumn{1}{c}{ Percent (\%) } & & 60.49 & 20.44 & 8.84 \\
\multicolumn{1}{c}{ Cumulative percent (\%) } & & 60.49 & 80.93 & 89.76 \\
\hline
\end{tabular}

*: T, C and F for texture, creep and fracture test, respectively.

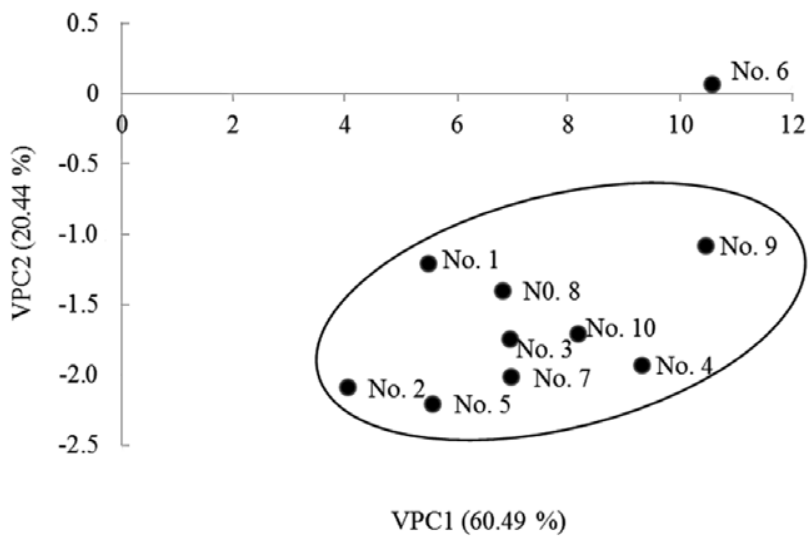

Fig. 7 Positioning map demonstrating viscoelastic characteristics of the samples.

外にプロットされた No.6 は，VPC1 と VPC2 双方の主成 分得点に影響を受ける特異なサンプルであり, Fig. 5 で 示したように高い破断および最大荷重值に依存して他の サンプルと比べて固い食感を与えることがわかった。

\section{2 官能評価と嗜好度の調查}

\subsection{1 官能評価特性の分類}

実用官能評価用語 38 語の評価スコアと消費者パネル による嗜好度の平均值，分散，標準偏差をそれぞれ Table 5 に示した。評価スコアおよび嗜好度の分散分析 結果については，その有意確率（p值）を示し，嘹好度 にはその得点順位をそれぞれ示した。

官能評価用語「パン様の酵母」( $p=0.37)$,「マッシュ ルーム」 $(p=0.91), 「 ホ ゚ テ ト 」(~ p=0.94)$ などの風味抢 よび「甘味」 $(p=0.06)$ は， $5 \%$ の有意水準でサンプル 間にスコアの差がないことがわかった。 その要因には, 評価用語の評価対象がすべての供試サンプルに同等程 度に存在する場合と評価用語のサンプル識別能力がな い場合の 2 通りがあると考えられたが，分散分析の結 果のみからではその判定はできなかった。そのため, これらの用語についてはサンプル差を識別できるとは いえない評価用語であると判断した。しかしながら， 評価用語のサンプル識別能力と他の評価用語との相互 関係は独立の事象であるため, 評価用語間の相互関係 に関する分析は続行可能と考えられた。

評価スコアおよび嗜好度に相関分析を適用した結果， 相関係数 $|R|>0.80$ を基準として，相関の高い組み合 わせが 741 組中 90 組あった。 そのうち評価属性が異な る項目間で高い相関がみられた組み合わせは 29 組で あった，他方，香味属性の「ヨーグルト臭」 $(\mathrm{R}=0.86$, $p<0.05)$ と「甘味」 $(\mathrm{R}=0.83, p<0.05)$ は喏好度と高 い相関を示し，これらの用語は嗜好度に寄与する官能 評価特性であることがわかった。

\subsection{2 官能評価スコアの主成分分析}

官能評価スコアに主成分分析を適用して得られた 6 


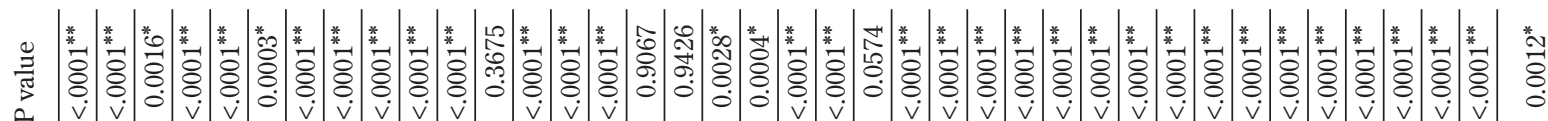

$\circ$ क人

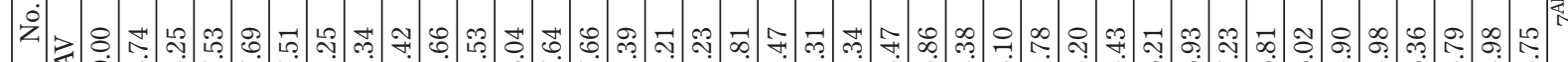

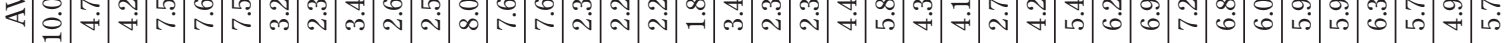

0. क人

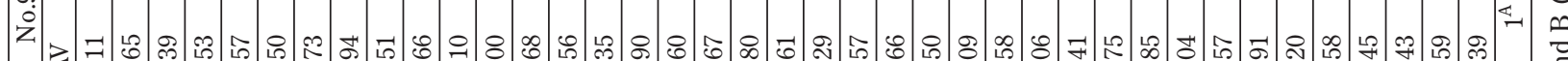

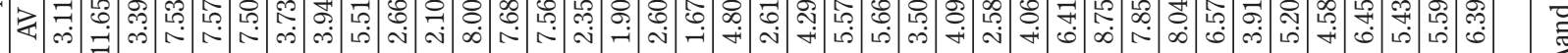

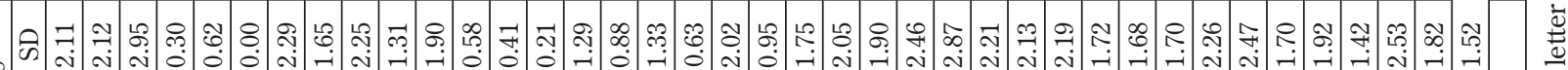

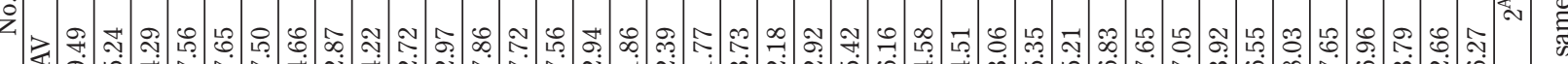

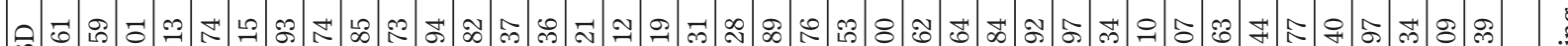

Zे

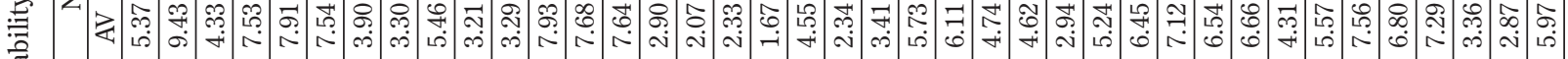

की

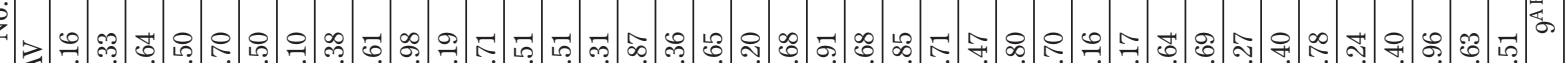

के की

की

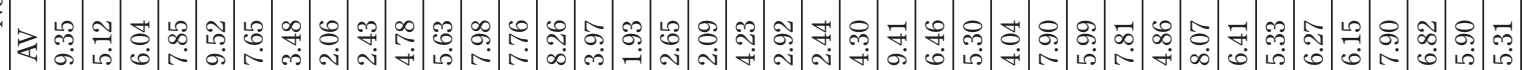

舟

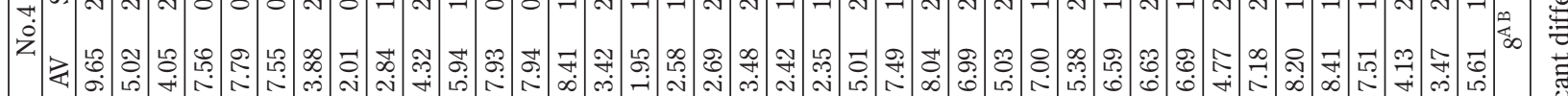

की \begin{tabular}{c}
$\dot{3}$ \\
\hdashline
\end{tabular}

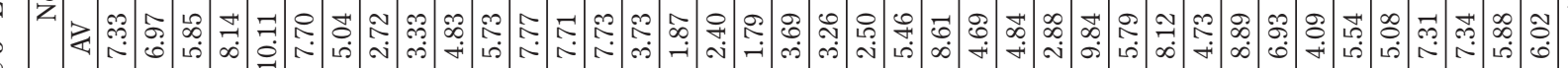

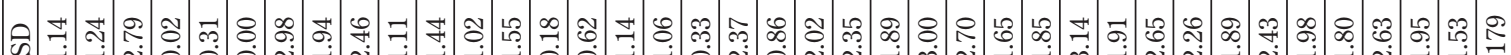
N

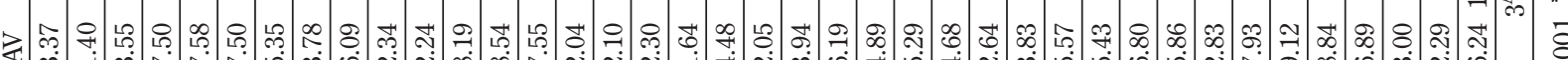
-

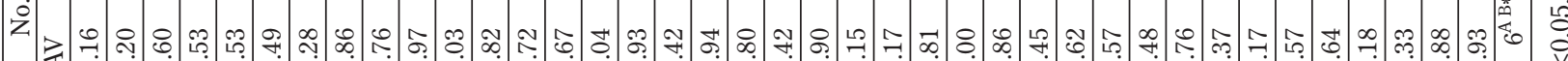

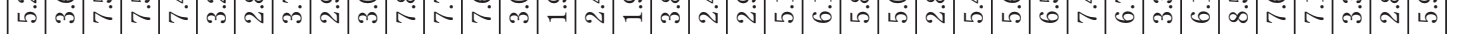

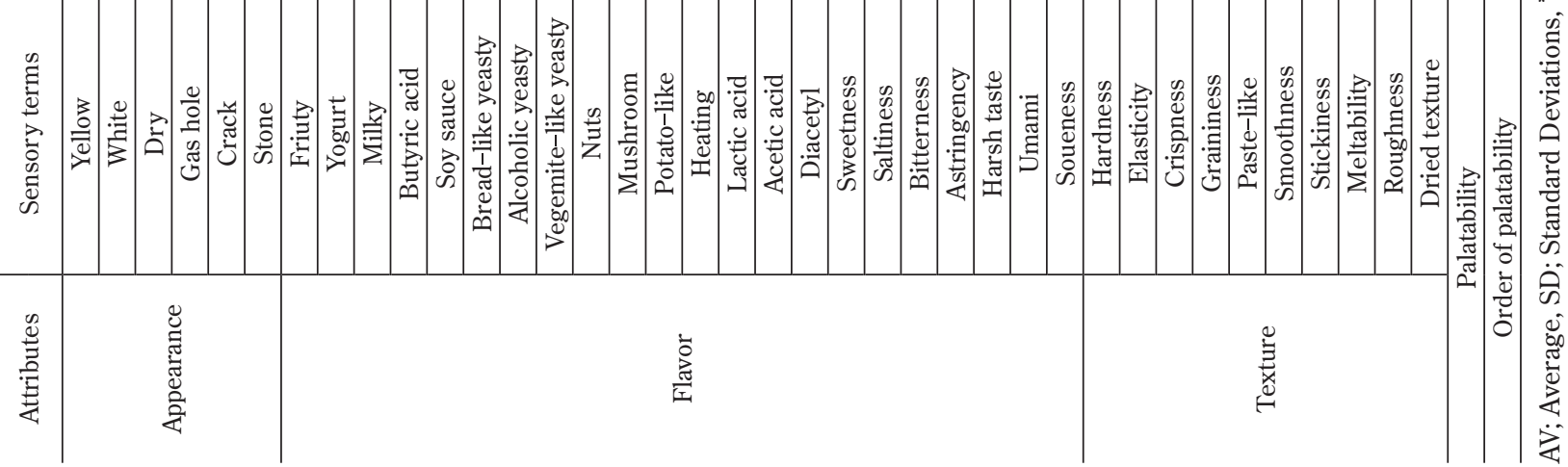


つの主成分とその因子負荷量および寄与率を Table 6 に示す。この表では粘弾性の VPC と区別して官能評価 (Sensory evaluation) スコアの主成分を SPC と表記し た.

SPC1 には主に外観属性と香味属性の評価用語が含ま れたが，いずれも前述した評価用語の相関分析におい て異なる評価属性の項目であるにも関わらず高い相関 を示す組み合わせが含まれていた，他方，SPC2 には食 感属性用語のみが含まれており，いずれの用語間にお いても相関が高いことを確認した. SPC 3 には $|\mathrm{R}|>0.60$ $(p<0.05)$ の相関をもつ外観属性の「白色」,「黄色」と 香味属性の用語が複数含まれた。これらの評価用語は チェダーチーズなどの乳製品のおいしさに寄与する用 語であることが知られている [20-22]．SPC4には，「加
熱風味」,「ポテト風味」,「エグ味」（ $p<0.0001 ）$ および 「苦味」のように，チーズのディフェクト，すなわち久 味や不快な風味として認識される用語が含まれた $[23-$ 27]. SPC5 およびSPC6 に含まれた「マッシュルーム」 と「パン様の酵母」風味，および「打酒様の酵母風味」 と「フルーティ」の間には $\mathrm{R}=0.67 \sim 0.70$ の相関がある 評価用語がそれぞれ含まれることがわかった.

これらの主成分分析結果より，官能評価用語はその 評価属性に関わらず区分することが可能であることが わかり，それら主成分の共通点を基にそれぞれ SPC1「外 観と味」, SPC2「食感」, SPC3「乳製品の扔いしさに関 与する基本特性」, SPC4「ディフェクト」, SPC5「マッ シュルームとパン様の酵母風味」および SPC6「打酒様 の酵母風味とフルーティ」とラベリングした. これら 6

Table 6 Principal components obtained from sensory scores and the label of principal components.

\begin{tabular}{|c|c|c|c|c|c|c|c|c|}
\hline $\begin{array}{l}\text { Label of principal } \\
\text { components }\end{array}$ & $\begin{array}{l}\text { Sensory } \\
\text { attribute }\end{array}$ & Sensory terms & $\mathrm{SPC1}$ & SPC2 & SPC3 & $\mathrm{SPC} 4$ & SPC5 & SPC6 \\
\hline \multirow{12}{*}{$\begin{array}{l}\text { Appearance and } \\
\text { acceptable tastes }\end{array}$} & \multirow{4}{*}{ Appearance } & Stone & 0.96 & & & & & \\
\hline & & Gas hole & 0.95 & & & & & \\
\hline & & Crack & 0.94 & & & & & \\
\hline & & Dry & 0.92 & & & & & \\
\hline & \multirow{6}{*}{ Flavor } & Umami & 0.92 & & & & & \\
\hline & & Acetic acid & 0.89 & & & & & \\
\hline & & Butyric acid & 0.86 & & & & & \\
\hline & & Saltiness & 0.83 & & & & & \\
\hline & & Nuts & 0.80 & & & & & \\
\hline & & Soy sauce & 0.76 & & & & & \\
\hline & \multirow{2}{*}{ Texture } & Meltability & 0.64 & & & & & \\
\hline & & Elasticity & -0.91 & & & & & \\
\hline \multirow{8}{*}{$\begin{array}{l}\text { Rehological } \\
\text { properties }\end{array}$} & \multirow{8}{*}{ Texture } & Smoothness & & 0.97 & & & & \\
\hline & & Stickiness & & 0.95 & & & & \\
\hline & & Paste-like & & 0.90 & & & & \\
\hline & & Roughness & & -0.79 & & & & \\
\hline & & Hardness & & -0.86 & & & & \\
\hline & & Crispness & & -0.89 & & & & \\
\hline & & Graininess & & -0.91 & & & & \\
\hline & & Dried texture & & -0.95 & & & & \\
\hline \multirow{8}{*}{$\begin{array}{l}\text { Basic properties } \\
\text { contributing to } \\
\text { palatability of } \\
\text { dairy products }\end{array}$} & Appearance & White & & & 0.96 & & & \\
\hline & \multirow{6}{*}{ Flavor } & Diacetyl & & & 0.94 & & & \\
\hline & & Yogurt & & & 0.90 & & & \\
\hline & & Lactic acid & & & 0.81 & & & \\
\hline & & Milky & & & 0.80 & & & \\
\hline & & Sweetness & & & 0.75 & & & \\
\hline & & Soureness & & & 0.61 & & & \\
\hline & Appearance & Yellow & & & -0.96 & & & \\
\hline \multirow{6}{*}{$\begin{array}{c}\text { Flavors act as } \\
\text { defects }\end{array}$} & \multirow{6}{*}{ Flavor } & Vegemite-like yeasty & & & & 0.85 & & \\
\hline & & Heating & & & & 0.83 & & \\
\hline & & Potato-like & & & & 0.83 & & \\
\hline & & Harsh taste & & & & 0.81 & & \\
\hline & & Bitterness & & & & 0.70 & & \\
\hline & & Astringency & & & & 0.68 & & \\
\hline \multirow{2}{*}{$\begin{array}{l}\text { Mushroom and } \\
\text { bread-like yeasty }\end{array}$} & \multirow{2}{*}{ Flavor } & Mushroom & & & & & 0.89 & \\
\hline & & Bread-like yeasty & & & & & 0.75 & \\
\hline \multirow{5}{*}{$\begin{array}{c}\text { Alcoholic yeasty } \\
\text { and fruity }\end{array}$} & \multirow{2}{*}{ Flavor } & Alcoholic yeasty & & & & & & 0.63 \\
\hline & & Friuty & & & & & & 0.59 \\
\hline & \multirow{2}{*}{\multicolumn{2}{|c|}{$\begin{array}{c}\text { Variance } \\
\text { percent }(\%)\end{array}$}} & 10.83 & 9.32 & 7.35 & 5.51 & 2.48 & 1.49 \\
\hline & & & 28.51 & 24.54 & 19.34 & 14.49 & 6.52 & 3.92 \\
\hline & \multicolumn{2}{|c|}{ Cumulative percent (\%) } & 28.51 & 53.05 & 72.39 & 86.88 & 93.40 & 97.32 \\
\hline
\end{tabular}


つの主成分は予め分類した官能評価属性とは異なる評 価対象属性に分類されたが，これは官能評価では人の 五感コミュニケーションを介して評価したスコアを提 供したことを示していると推察した，通常，官能評価 ではパネルに対して評価属性に分類した用語について 独立に評価する訓練を実施しているが，個々の用語に ついて完全に独立した用語としてみなすには限界があ り，すでに評価パネリスト個人の潜在意識下で構成さ れている官能評価属性および用語間の相関を排除する ことは困難であると考えられた。したがって，KJ 法な ごを利用して整理して設定された評価属性打よび用語 を用いて官能評価を行い，そのスコアを主成分分析す ることにより，パネリストがすでに保有している独自 の官能評価体系を抽出することが可能であると考えら れ，その抽出された官能評価体系を採用することによ り，個人の五感コミュニケーション効果を含めた官能 評価法を創出する可能性が残されていると考えられた。

官能評価スコアの主成分分析から分類された新たな官 能評価属性に基づいて，SPC1 と 2 および SPC3 と 4 の 主成分得点による供試サンプルのポジショニングマップ をそれぞれ Fig. 8 (a) 扎よび (b) に示し，またこれらのサ ンプルの嗜好度とその順位を Table 7 に示す。

Fig. $8(\mathrm{a})$ に示すように，官能評価用語の主成分得点 に影響を受けるサンプルはグループ A， B， C に分けら

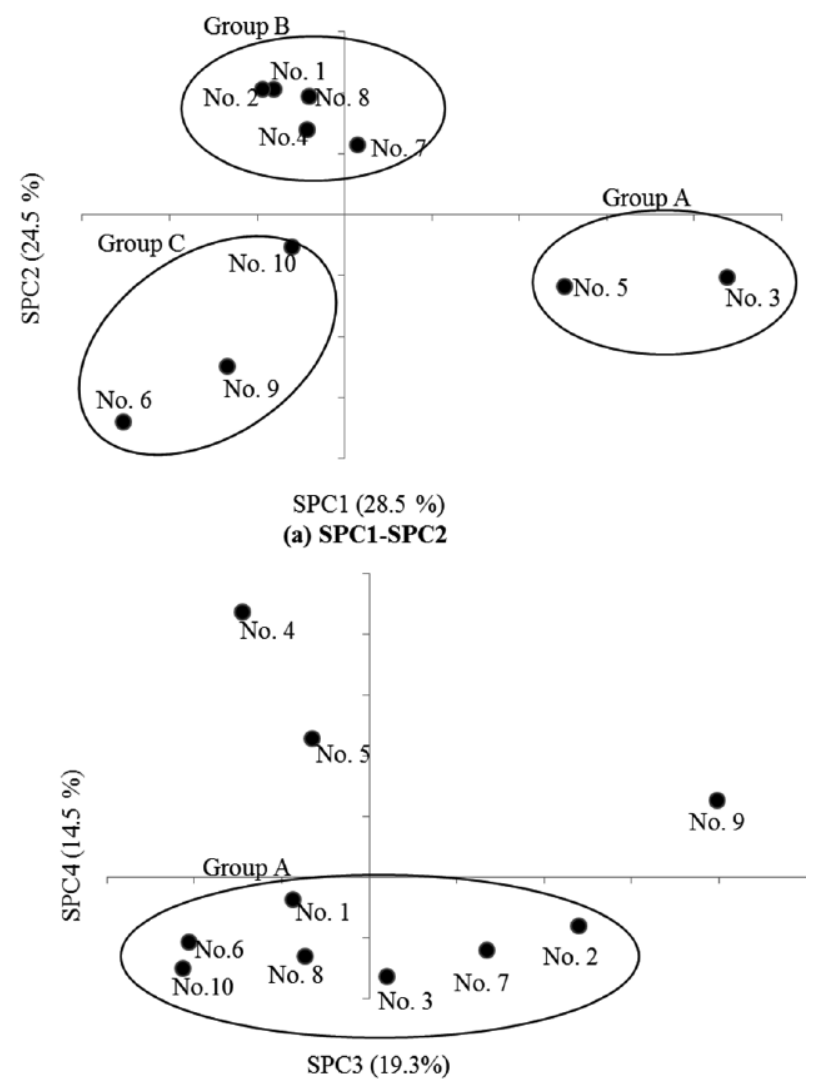

(b) SPC3-SPC4

Fig. 8 Positioning map by sensory characteristics of the samples.
Table 7 Palatability scores and ranking.

\begin{tabular}{lcc}
\hline \multirow{2}{*}{ Sample } & \multicolumn{2}{c}{ Palatability } \\
\cline { 2 - 3 } & Score & Ranking \\
\hline No.1 & 5.93 & 6 \\
No.2 & 6.24 & 3 \\
No.3 & 6.02 & 4 \\
No.4 & 5.61 & 8 \\
No.5 & 5.31 & 10 \\
No.6 & 5.51 & 9 \\
No.7 & 5.97 & 5 \\
No.8 & 6.27 & 2 \\
No.9 & 6.39 & 1 \\
No.10 & 5.75 & 7 \\
\hline
\end{tabular}

れることがわかった.グループ A は SPC1の主成分得 点に影響を受け，食感属性用語の影響を受けるサンプ ルはグループ B とCに分けられた. Fig. 8(b)のポジョョ ニングマップに示すように，大部分のサンプルがグルー プ Aに含まれ，SPC3 の評価用語に影響を受けるサンプ ルであることがわかった. サンプル No. 9 はこの平面 の第一象限にプロットされ，Table 7 で示されるように 最高の嗜好度順位にあることがわかった。逆に，第 4 象限にプロットされたサンプル No.4 と 5 は, グループ $\mathrm{A}$ に比べても低い嗜好度順位を示した。これらのポシ ショニングマップから，嗜好度順位に影響を及ぼす主 成分は SPC3 と SPC4 であることがわかった。したがっ て，SPC3を「乳製品の扎いしさに関与する基本特性」, また SPC4 を不快な風味すなわち「ディフェクト」と ラベリングしたことには妥当性があると考えた。 これ らの結果を嗜好度に寄与する主成分得点の観点から評 価すると, Fig. 8(b)に示した SPC3 の貢献が最も高く, (a)に示したSPC1 と 2 の示す貢献度よりも強いことが わかった。したがって，SPC3 に含まれる評価スコアの 嗜好度への貢献度は，例えば SPC1の主成分得点の上 位 4 位までを占める外観属性用語よりも高いことがわ かった。

\section{3 咀嚼過程における食感と粘弾性計測特性との対 応関係}

Table 6 の主成分分析結果に示すように，SPC2 に含 まれる食感属性の評価用語は，機器計測で得られる粘 弾性パラメータと高い相関を示すことが予測された。 そこで，粘弾性パラメータと食感用語スコアをデータ ベースとして両者の対応関係を咀嚼回数に基づいて整 理することとした. Fig. 9 に典型的な 2 バイト咀嚼によ る荷重経時変化曲線と粘弾性試験法の対応関係を示し た。この曲線にしたがって人が感じる食感を図中の (1), (2)，（3）の 3 段階に分類すると，3つの試験法は (1') ク リープ，(2’)破断，（3’）テクスチャ試験に相当すると考 えられた。ここで，クリープ試験では破断試験で得ら れる荷重一歪率曲線の初期段階に出現する線形近似直 
Typical force vs. time curve measured during two bites

(1) Small deformation shortly after first touch of sample

(2) Large deformation until first bite

(3) Large deformation until second bite

(3)

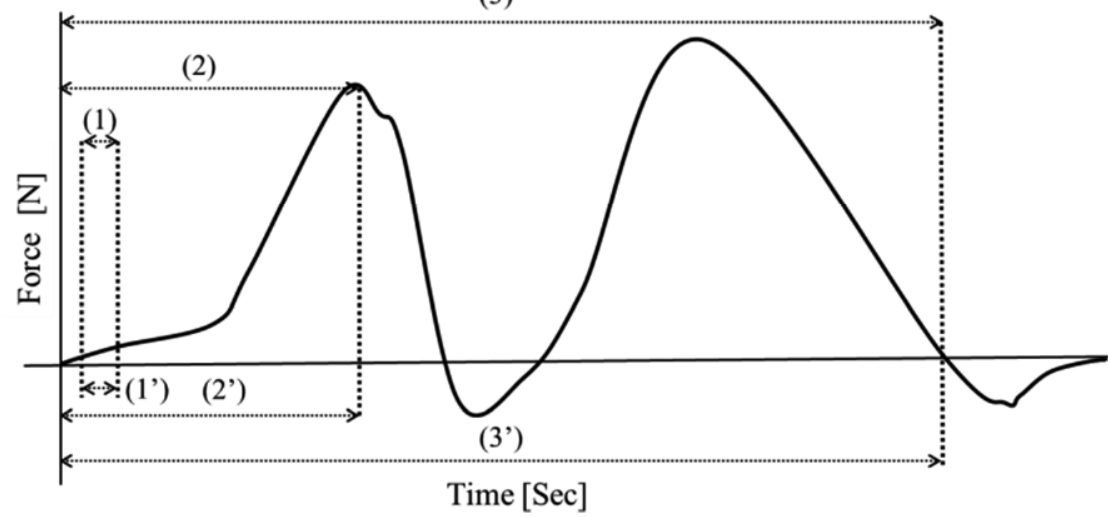

Instrumental test

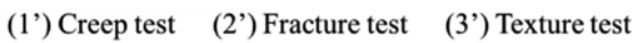

Fig. 9 Typical force vs. time curve measured during two bites comparing with creep, fracture and texture tests.

線の範囲，すなわちサンプルが弾性的挙動を示す範囲 の最大荷重を載荷荷重として用いた。ささらに両試験法 で得られるパラメータの定義も一致することから, ク リープ試験および破断試験で得られた粘弾性パラメー タはデータ解析に打いては同一の試験カテゴリーで得 られるパラメータとして扱えると考えられた，他方， テクスチャ試験パラメータは 2 バイトによる荷重経時 変化曲線から推算されるパラメータであり，その定義

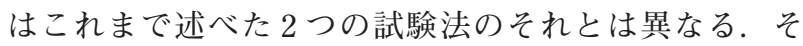
のため，この試験法で得られるパラメータはデータ解 析でも単独に取り扱う必要があると考えた。これらの 考察に基づいて, Fig. 9 に示した人の口腔内で感じる食 感変化と粘弾性試験法との対応関係を時系列的に説明 可能であると考えられた.

この考え方に従って，粘弾性パラメータと食感評価 スコアとの相互関連性を明らかにするためには，その 評価スコアが Fig. 9 の曲線中のどの段階で生じたのか を明確にし，その段階に対応する粘弾性試験法を選択 する必要があると考えた。その手順を説明するための フローチャートを考案して Fig. 10 に示す。この罒に示 すように，サンプル試片を 3 つの試験法（図中の IC, IF およびIT）に供し，これらの試験法の異なる変形条 件下で得られる粘弾性パラメータを測定し，それらの 中から官能評価（図中の SA，SC）スコアに対応するパ ラメータを選択することによって，粘弾性特性と食感 との対応関係を明らかにする。ここで選択したパラメー タの組み合わせによってはPLS-VIP による変数選択を 行い，これらの変数を入力とする ANN モデリングを行 う。この手順に従って機器計測パラメータと評価スコ アとの相互関連性を明らかにするモデルを構築するこ
とにより，官能評価スコアの予測に最適なパラメータ の組み合わせを求めることができ，機器計測による物 性と官能評価で得たデータを適切に比較検討できるよ

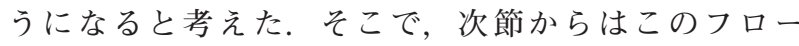
チャートに従って供試サンプルの粘弾性パラメータと 食感評価スコアおよび嗜好度の相互関連性について考 察した。

\section{4 食感評価スコアの予測に最適な粘弾性特性の探 索法}

フローチャート（Fig. 10）に示した試験法と官能評 価によって，食感評価スコアの予測に最適な試験法の 組み合わせをPLS 回帰分析により探索した。 3.3 で述べ たように，説明変数としたパラメータのうち，テクス チャ試験で得られたパラメータは独自の試験カテゴ リーで得られたパラメータとして扱い，他の 2 つの試 験法で得られたパラメータと区分して取り扱った。こ れら 2 つ試験カテゴリーに分類したパラメータを PLS 回帰分析の説明变数とし，目的変数の食感評価ス コアを予測する回帰式を求めた。これらの中で最も高 い予測精度を示す回帰式のパラメータの組み合わせを 選択し，ANN モデリングによりパラメータ群と評価ス コアとの相互関係を予測した。

このようにして得られた ANN モデルは，粘弾性パラ メータおよび食感評価スコア間の非線形関係やパラ メータ間のシナジー効果を応答曲面により表示するこ とが可能である。ささら，モデルに適用するパラメー タの值を増減させることにより，現在実施されている 粘弾性計測と官能評価などの結果を数值シミュレー ションできると考えた. 


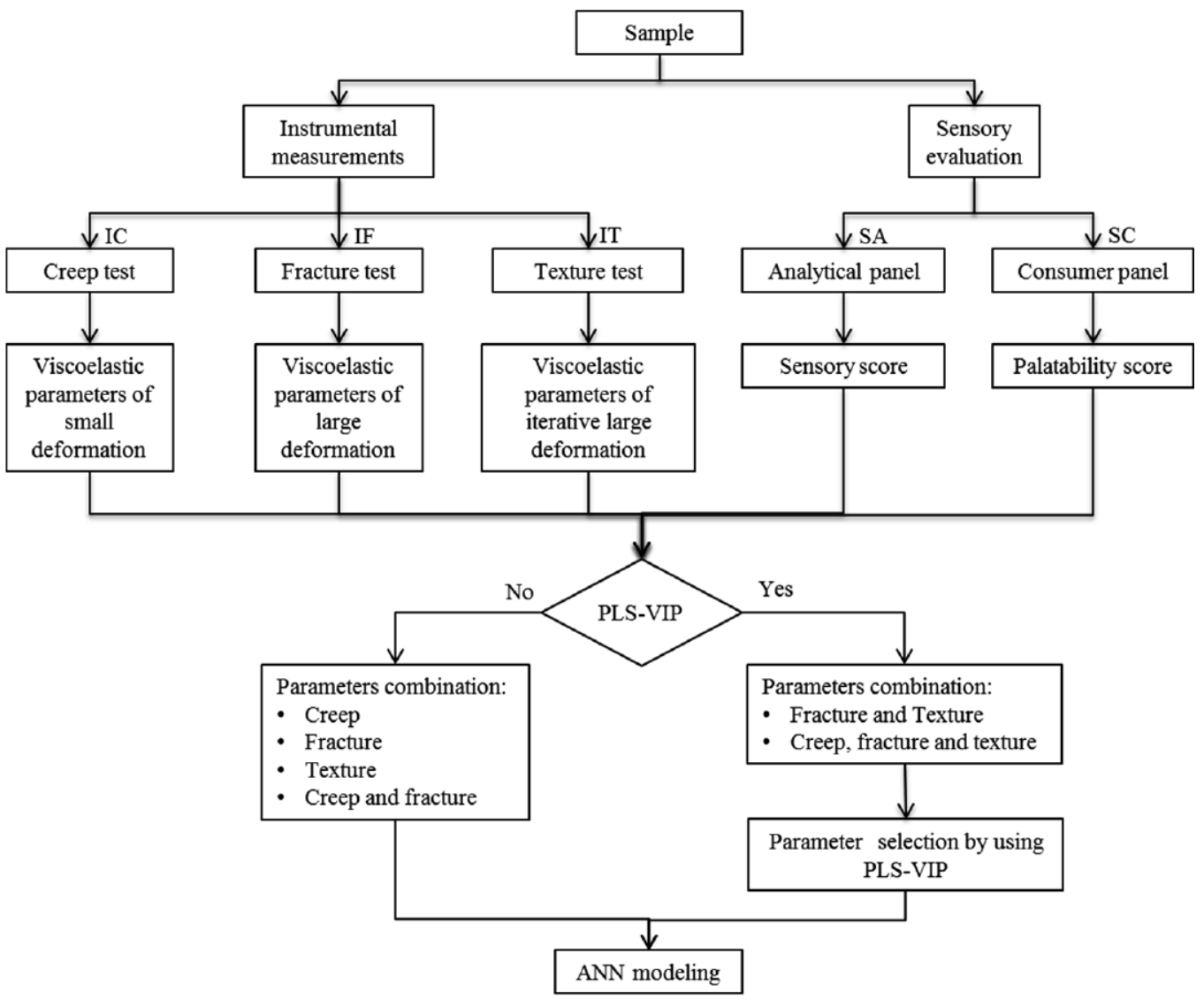

Fig. 10 Procedure to construct optimal ANN model by using PLS as a selection indicator.

\subsection{1 食感評価と対応する粘弾性試験法の組み合わせ}

Table 8 に食感属性 10 語の評価スコアに関する PLS 回帰式の予測精度一覧を示す。それぞれの評価スコア について，1）～3）に試験法を単独で使用した場合，4）

〜6) に組み合わせた場合を口腔内での食感経時変化 (Fig. 9) に従って示す.

食感評価スコアは，複数の試験法を組み合わせて使 用した場合に最も高い予測精度を示す傾向が認められ た。これらの試験法の組み合わせ方法について，まず， 回帰式の予測精度，次に粘弾性パラメータが同一の試 験カテゴリーで得られたパラメータとして取り扱える 組み合わせである可能性，最終的に，他の組み合わせ 法との予測精度の差の有意性の 3 つの基準に基づいて 判断し，Fig. 10 に示すような煩雑な解析手順，すなわ ち PLS-VIPによる変数選択の必要がなく，最も高い食 感評価スコアの予測精度を得られる組み合わせ法を求 め，それらをa）〜c）に分類して述べた.

a）すべての試験法の組み合わせ

「ざらつき」,「なめらかさ」および「乾燥した食感」は, すべての試験法で得られたパラメータを使用した場合 に最も予測精度が高く（ $\mathrm{R}^{2}=0.89 ， 0.99$ および 0.96$)$, これらの食感に対しては，供試サンプルの初期圧縮で 生ずる微小変形とその後の咀嚼による大変形に関係す るパラメータが複合的に作用していると考えられた。 b）任意に選んだ試験法の組み合わせ

「かたさ」，「弾力」，「歯切れのよさ」，「ねっとり感」 および「ペースト状」では，2３種の試験法を任意に 組み合わせれば， $\mathrm{R}^{2}=0.96 \sim 0.99$ の範囲で高精度の予測 が可能であることがわかった。すなわち，これらの評 価スコアの予測にはパラメータの種類を厳選するより も，少なくとも 2 つ試験法を組み合わせることによ り高い予測精度を得られることがわかった。例えば，「か たさ」と「弾力」は 4）もしくは5）の組み合わせで最 も高い予測精度を示した。これは2）の場合の予測精度 $\mathrm{R}^{2}=0.94$ がクリープとテクスチャ試験をそれぞれ単独 で使用した場合の $\mathrm{R}^{2}=0.28 \sim 0.44$ と比較して顕著に高 く，破断試験のパラメータの重要性がわかった。他方， 「歯切れのよさ」，「ねっとり感」扎よび「ペースト状」 の評価スコアは，いずれも単独試験 1）の場合の予測精 度が，同様に2）と3）を使用した場合と比べて顕著に 低いことから，この 3 語の予測精度に対するクリープ 試験の重要性は低いと考えられた。

c）テクスチャ試験の単独使用

これまでの試験法の組み合わせでその予測精度につ いて言及できなかった「口溶けのはやさ」と「粗さ」は， テクスチャ試験を単独で使用した場合に，それぞれ $\mathrm{R}^{2}$ $=0.82 \sim 0.87$ の範囲で高い予測精度を示したが，これは どちらの用語についても咀嚼の繰り返しによる試片の 


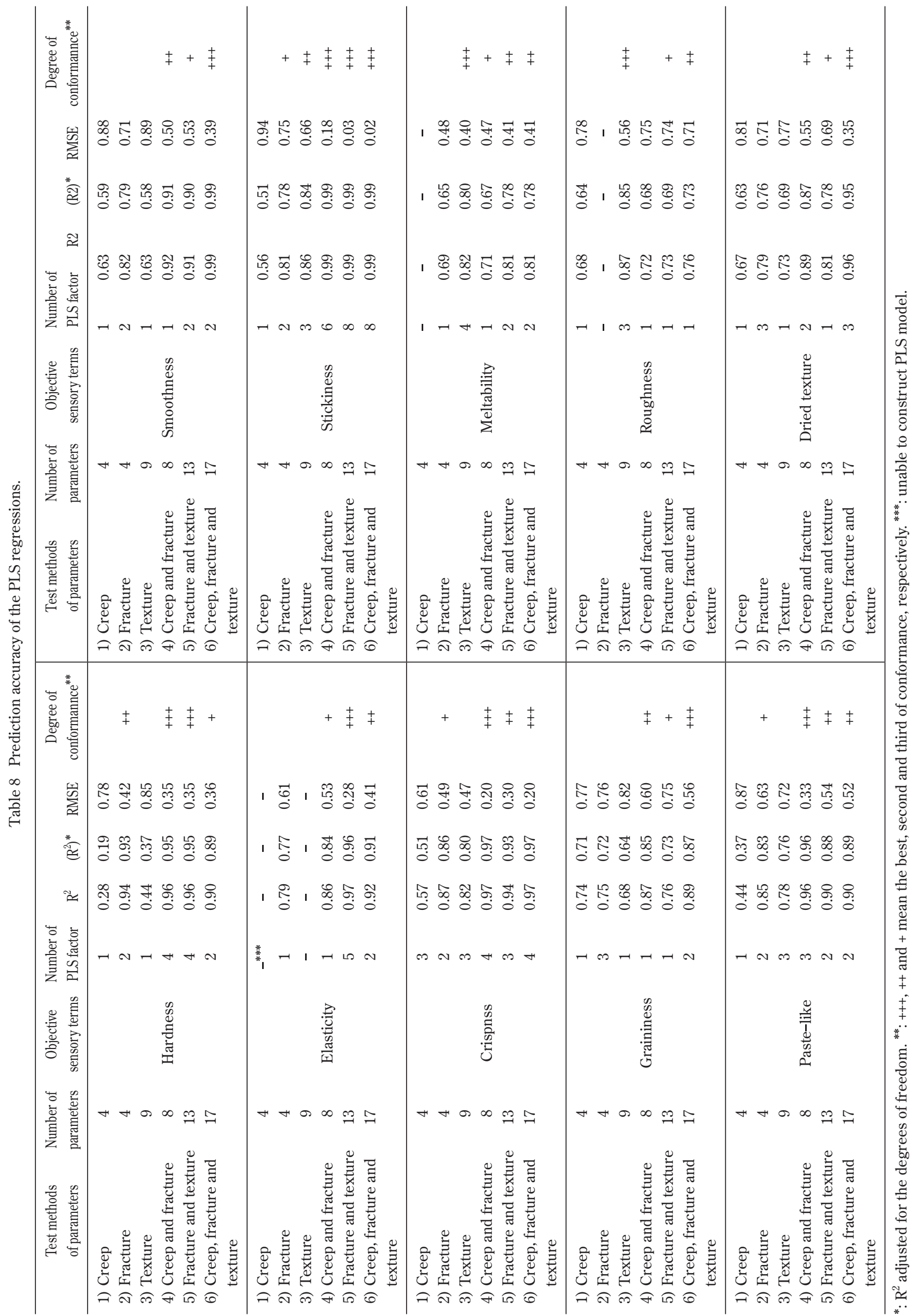


大変形を計測したテクスチャ試験のパラメータとの親 和性が最も高くなったためであると考えられた。とく に「口溶けのはやさ」は，試験法の組み合わせ 5）打よ び 6) の場合でも $\mathrm{R}^{2}=0.81$ を示しており，テクスチャ 試験単独で計測した場合と複数の試験法を組み合わせ た場合との差は観られず，計測作業の簡素化のために はテクスチャ試験のみを選択できると考えられた。

これまで述べたPLS 回帰式の予測精度に関する考察 から，上記 a）で述べたすべての試験法の組み合わせを 採用した場合にはテクスチャ試験のパラメータが混在 するため ANN モデリングの入力パラメータを PLSVIP 法で選択する必要があると考えられた。他方，b） の組み合わせ法の中で，クリープ試験と破断試験の組 み合わせを用いると直接 PLS-VIP 法を適用せずに ANN モデリングが可能となることがわかった。

\subsection{2 クリープ試験と破断試験の組み合わせによる} 食感の ANN モデリング

Table 8 において「かたさ」スコアの予測に適する試 験法の組み合わせは，回帰式の予測精度が $\mathrm{R}^{2}=0.96$ を 示した 4）と5）の組み合わせであった。ここで，Fig. 10 に従うと, データ解析に打いて同一の試験カテゴリー 内のパラメータであると考えられた 4） クリープ試験と 破断試験を組み合わせて用いる方法であれば，これら の試験法で得られるパラメータは直接 ANN モデリング の入力データとして使用できるため，これらの粘弾性 パラメータの組み合わせが最適であると判断した。そ の典型例として「かたさ」スコアを予測するために， クリープ試験と破断試験で得られるパラメータ（パラ メータ数：8）を ANNの入力層に適用し，「かたさ」ス コアを出力層とした ANN モデリングを実施した。モデ ルの構築にあたっては，学習セットに対するオーバー フィットペナルティを 0.001 に設定し，モデリング毎に 出力される決定係数を用いてモデルの安定を確認した.

その結果，得られた ANN モデルでシミュレートした 破断試験とクリープ試験のパラメータの例として，そ れぞれ破断荷重と弾性率 $E_{1}$ 打よび「かたさ」スコアの 関係を選択して応答曲面 $\mathrm{ABCD}$ を Fig. 11 に示した。こ のモデルの予測精度は $\mathrm{R}^{2} \mathrm{c}=0.96$ および $\mathrm{R}^{2} \mathrm{v}=0.83$ であ り，底面座標の両パラメータの值が高くなるにつれて 「かたさ」スコアも高く評価される傾向を示した。 また， この応答曲面の範囲内に扎ては破断荷重が $105 \mathrm{~N}$, 弾 性率 $E_{1}$ が $45 \times 10^{5} \mathrm{~Pa}$ のとき「かたさ」スコアの極大点 (LMP: Local Maximum Point) 7.65 を示した. ここで,

Fig. 3 で示したように弾性率 $E_{1}$ は 4 要素モデルの遅延 変形部のバネに相当することから，供試サンプルの食 感に打ける「かたさ」は弾性率 $E_{1}$ に相当するバネの硬 さに相関を示すと考えられた。

両試験法の計測方法より，これらの粘弾性パラメー タの定義は同一であるため，このモデルによって「か

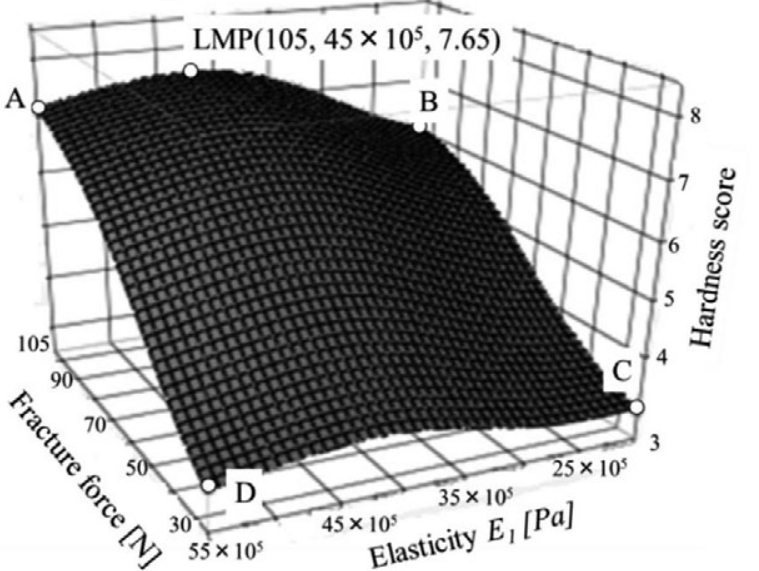

$\mathrm{R}^{2} \mathrm{c}$ (calibration) $=0.96$, RMSEc $=0.38$ $\mathrm{R}^{2} \mathrm{v}$ (validation) $=0.83, \mathrm{RMSEv}=0.28$

Fig. 11 Responded curved surface of the relationship among fracture force, elasticity $E_{1}$ and sensory score of 'hardness' obtained by ANN modeling (LMP: Local maximum point)

たさ」スコアを破断荷重と弾性率 $E_{1}$ の值の操作によっ てコントロールできる可能性を示した.

3.4.3すべての試験法のパラメータによる食感の ANN モデリング

PLS-VIPによる変数選択が必要な試験法の組み合わ せにより得られる「なめらかさ」スコアのモデリング について述べる．PLS-VIP を変数選択に使用する場合 には，VIP $>1.0$ を示す説明变数の選択が一般的に行わ れている [28-30] が，本研究では JMP10.0Pro のデフォ ルトとして推奨されている $\mathrm{VIP} \geqq 0.80$ および $\mathrm{W}= \pm 0.1$ を閾值として採用した。

ステップワイズ PLS-VIP 法を目的変数「なめらかさ」 のスコアに適用した結果，Fig. 12 に示すように，第 3

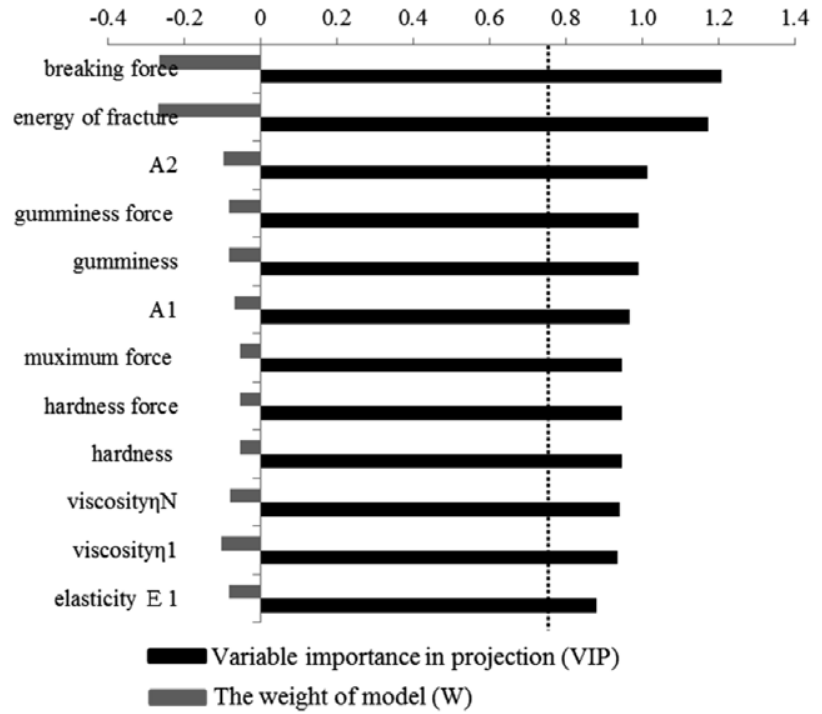

Fig. 12 Viscoelastic parameters contributing to sensory term 'smoothness' obtained by 3rd trial of stepwise PLS-VIP. 
試行時に 12 個のパラメータが「なめらかさ」に影響を 及ぼすパラメータとして選択され，それらの寄与度の 順位が明らかになった。このような変数選択の結果か ら,「なめらかさ」スコアには破断荷重と破断エネルギー のように供試サンプルの破断試験から得られるパラ メータとともにガム性荷重打よび応力のようなテクス チャ試験から得られるパラメータが寄与することがわ かった.

変数選択で得られた 12 個のパラメータを ANNの入 力層に適用し，それらのパラメータと「なめらかさ」 スコア間の非線形モデルを構築したところ，その予測 精度 $\mathrm{R}^{2} \mathrm{c}=0.98$ 打よび $\mathrm{R}^{2} \mathrm{v}=0.93$ が達成された。構築し たモデルのうち，試験カテゴリーの異なる粘弾性パラ メータの組み合わせの例として, 破断試験とテクスチャ 試験のパラメータからそれぞれ破断荷重，かたさ荷重 および「なめらかさ」スコアを選び，その相互関係を 示す応答曲面を Fig. 13 に示す．得られたモデルの解釈 を行うために，テクスチャ試験のパラメータを他の試 験法のパラメータと同様に独立変数とみなすと，この 応答曲面では破断荷重 $30 \mathrm{~N}$ ， かたさ荷重 $4.5 \mathrm{~N}$ のとき に点 B が「なめらかさ」の極大スコア 7.73 を示すこと がわかった。このようにPLS-VIPの適用法については, テクスチャ試験のパラメータを単独で使用することは 可能であるが，定義の異なる他の試験カテゴリーから それぞれ得られたパラメータと組み合わせて予測する 場合には，兑の利用法に留意する必要があると考えら れた。

以上の考察から，PLS-VIPを使って ANN モデルを
構築する場合には，シミュレーションのパラメータ選 択に同一の試験カテゴリーの中から得られたパラメー タを使用する必要があると考えられた。

\section{5 粘弾性特性によって嗜好度を予測するモデルの 構築}

チェダーチーズの品質評価に打いて，その食感から 嘹好度を予測することが可能となれば，消費者に好ま れる粘弾性特性をもつ製品を設計することが可能にな ると考えられた，そこで， 3.4 項に述べた手法を用いて 赀好度のANN モデルの構築を試みた。

\subsection{1 粘弾性特性と嗜好度間の相互関係予測モデル}

これまでに述べた考察により，テクスチャ試験から得 られる9個のパラメータ数は, クリープ試験および破断 試験でそれぞれ得られるパラメータ数 4 個よりも多く, また，これらのパラメータの独立性による制約を考える と，嗜好度のモデリングにはテクスチャ試験のパラメー タのみを使用することが最適であると考えた。

この条件に従って, ANN モデルの入力層にテクス チャ試験で得られた 9 個のパラメータ, 出力層に嗜好 度を適用した結果，その予測精度は $\mathrm{R}^{2} \mathrm{c}=0.93$ 打よび $\mathrm{R}^{2} \mathrm{v}=0.83$ を達成した。構築したモデルのうち, 付着性, 凝集性打よび嗜好度の相互関係を示した応答曲面を Fig. 14 に示す.この応答曲面の範囲内に打いて，嗜好 度は付着性 $20\left[\mathrm{~J} / \mathrm{m}^{3}\right]$ 打よび疑集性 0.68 のとき極大点 $\mathrm{B}$ $=7.48$ を示すことがわかった。テクスチャ試験から得 られた粘弾性パラメータと嘹好度の相互関係は，曲面 のいずれの断面から観察しても非線形関係にあること

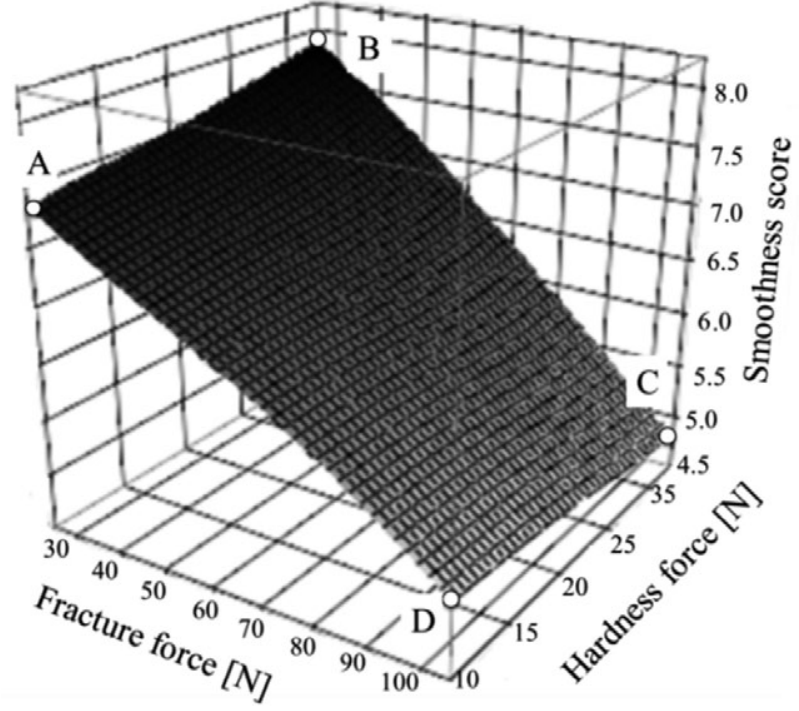

$\mathrm{R}^{2} \mathrm{c}$ (calibration) $=0.98$, RMSEc $=0.20$ $\mathrm{R}^{2} \mathrm{v}($ validation $)=0.93, \mathrm{RMSEv}=0.33$

Fig. 13 Response curved surface of the relationship among fracture and hardness force as well as sensory score of 'smoothness' obtained by ANN modeling.

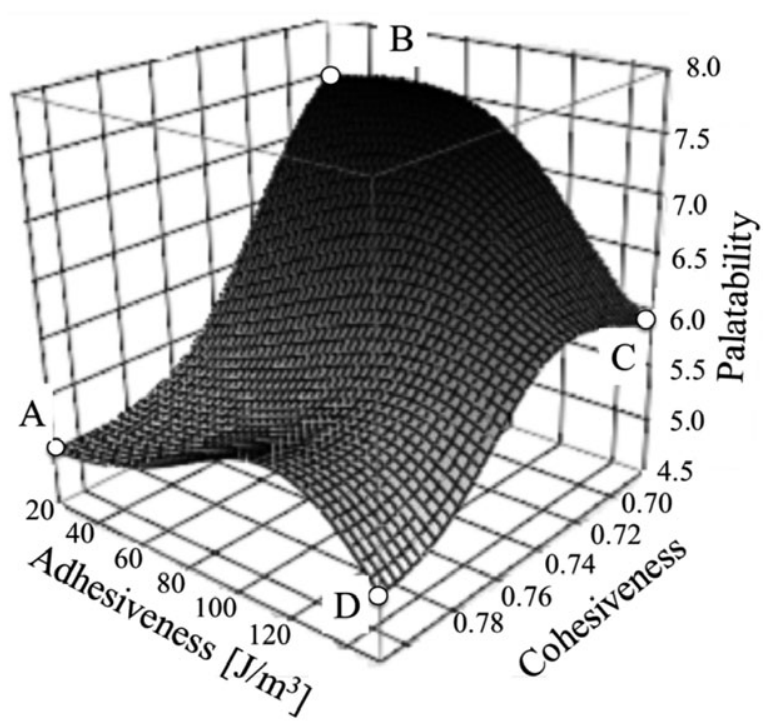

$\mathrm{R}^{2} \mathrm{c}$ (calibration) $=0.93$, RMSEc $=0.08$ $\mathrm{R}^{2} \mathrm{v}($ validation $)=0.83, \mathrm{RMSEv}=0.14$

Fig. 14 Response curved surface of the relationship among adhesiveness, cohesiveness and palatability obtained by ANN modeling. 
がわかった．また，この応答曲面はモデルの構築のた めに使用した 9 個すべてのパラメータの間に存在する シナジー効果を総合的に評価した結果を示していると 考えられた。したがって，このような方法で構築した ANN モデルから得られた応答曲面によって，消費者の 嗜好度を粘弾性計測パラメータの数值によってシミュ レーションすることが可能であると考えられた.

\section{4. 結論}

チェダーチーズの粘弾性計測パラメータと官能評価 スコアの相互関係解析に基づいて，高精度で官能評価 スコアを予測する機器試験法の組み合わせを選択する 方法打よび PLS 解析法と ANN モデリングを併用して 品質と嗜好度を評価するモデルを提唱した。

供試サンプルとして市販用打よびプロセスチーズ原 料用のチェダーチーズ 10 品を選定し，それらの粘弾性 特性に関して，破断，クリープおよびテクスチャの 3 試験法により粘弾性パラメータを取得した。他方, 外観, 香味抢よび食感属性の用語からなる官能評価用語 38 語 を選定し，それらを使用した分析型官能評価と消費者 嗜好度調査を実施して官能評価スコアおよび嗜好度を 得た．粘弾性パラメータの試験法の原理に基づき，破 断とクリープ試験を同一試験カテゴリーで得られた粘 弾性パラメータとして扱い，他方，テクスチャ試験は 単独試験法として前者の試験法とは区別してデータ解 析に供する必要があることを示した。官能評価により 得られた評価スコアの主成分分析の結果，評価用語は その評価属性に関わらず分類できることがわかり，こ れらは人の五感コミュニケーションを介して得られた 官能評価の結果を示していると考えられた。

供試サンプルの 2 バイト咀嚼による荷重経時変化曲 線に咀嚼過程における食感と粘弾性計測特性を対応さ せることにより，粘弾性パラメータと人の口腔内で感 じる食感変化との相互関係を時系列的に説明可能と考 えた。 また，この相互対応関係に基づき，官能評価ス コアが荷重経時変化曲線中のどの段階で生じる食感で あるのかを明確にし，咀嚼段階に対応する最適な粘弾 性試験法を選択するためのフローチャートを提示した。 このフローチャートに従って, PLS 回帰分析の予測精 度を比較することによって食感評価スコアに対応する 粘弾性パラメータを選択し，食感評価スコアに対応す る粘弾性試験法の組み合わせ法が 3 つに場合分けでき ることを示した。

咀嚼過程における食感と対応付けして区分した粘弾 性試験法によって得られた粘弾性パラメータから食感 評価スコアを予測する新しい解析法として，PLS 回帰 分析法と ANN モデリングを融合して利用する方法を提 唱した。この方法の導入によって，食感評価スコアの
予測に最も寄与する粘弾性試験法の組み合わせを選択 して ANN モデルを操作することが可能となった．また， 現在実施されている粘弾性計測と官能評価作業に代 わって，粘弾性パラメータの数值シミュレーションが 可能となった.

\section{引用 文 献}

1) E. A. Foegeding, M. A. Drake; Invited review: sensory and mechanical properties of cheese texture. J. Dairy Sci., 90, 1611-1624, (2007).

2) M. M. AK, S. Gunasekaran; Stress-strain curve analysis of cheddar cheese under uniaxial compression. J. Food Sci., 57, 1078-1081, (1992).

3) D. Jaros, W. Ginzinger, E. Tschager, H. K. Mayer, H. Rohm; Effects of water addition on composition and fracture properties of Emmental cheese. Lait., 4, 467-477, (1997).

4) C. Bugaud, S. Buchin, J.-B. Coulon, A. Hauwuy, D. Dupont; Influence of the nature of alpine pastures on plasmin activity, fatty acid and volatile compound composition of milk. Lait., 81, 401-414, (2001).

5) C. Bugaud, S. Buchin, Y. Noel, L. Tessier, S. Pochet, B. Martin, J. F. Chamba; Relationships between Abondance cheese texture, its composition and that of milk produced by cows grazing different types of pastures. Lait., 81, 593-607, (2001).

6) B. H. Lee, L. C. Laleye, R. E. Simard, R. A. Holley, D. B. Emmons, R. N. Giroux; Influence of homofermentative lactobacilli on physicochemical and sensory properties of cheddar cheese. J. Food Sci., 55, 386-390, (1990).

7) A. Lebecque, A. Laguet, M. F. Devaux, E. Dufour; Delineation of the texture of salers cheese by sensory analysis and physical methods. Lait., 81, 609-624, (2001).

8) C. J. Coker, R. A. Crawford, K. A. Johnston, H. Singh, L. K. Creamer; Towards the classification of cheese variety and maturity on the basis of statistical analysis of proteolysis data—a review. Int. Dairy J., 15, 631-643, (2005).

9) J. R. Stokes, M. W. Boehm, S. K. Baier; Oral processing, texture and mouthfeel: From rheology to tribology and beyond. Curr. Opin. Colloid Interface Sci., 18, 349-359, (2013).

10) G. Hough, A. N. Califano, N. C. Bertola, A. E. Bevilacqua, E. Martinez, M. J. Vega, N. E. Zaritzky; Partial least squares correlations between sensory and instrumental measurements of flavor and texture for Reggianito grating cheese. Food Qual. Prefer., 7, 47-53, (1996).

11) M. A. Drake, P. D. Gerard, V. D. Truong, C. R. Daubert; Relationship between instrumental and sensory measurements of cheese texture. J. Texture Stud., 30, 451-476, (1999). 
12) K. Adhikari, H. Heymann, H. E. Huff; Textural characteristics of lowfat, fullfat and smoked cheeses: sensory and instrumental approaches. Food Qual. Prefer., 14, 211-218, (2003).

13) G. Donadini, M. D. Fumi, L. VanonilI, S. Porretta; Hedonic response to cheese in preschoolers. J. Sens. Stud., 27, 176187, (2012).

14) H. Ochi, H. Naito, K. Iwatsuki, T. Bamba, E. Fukusaki; Metabolomics-based component profiling of hard and semihard natural cheeses with gas chromatography/time-offlight-mass spectrometry, and its application to sensory predictive modeling. J. Biosci. Bioeng., 113, 751-758, (2012).

15) H. Wium, K. B. Qvist, M. Gross; Uniaxial compression of UF-feta cheese related to sensory texture analysis. J. Texture Stud., 28, 455-476, (1997).

16) M. Shibata, T. Araki, Y. Sagara; Development of specified protocols and methodology in the application of food kansei model for the optimal design of danish pastry. Food Sci. Technol. Res., 14, 367-376, (2008).

17) Y. Sagara, "Kansei measuring methods for mechanical properties and texture of foods" (in Japanese). Nippon Shokuhin Kagaku Kogaku Kaishi, 56, 501-512, (2009).

18) ISO 11035:1994 (Internatinal Organaigation for Standaraization), Sensory analysis- Identification and selection of descriptors for establishing a sensory profile by a multidimentional approach. 1994.

19) ISO22935-2-IDF99-2 (International Organization for Standardization/International Dairy Federation), Milk and milk products-Sensory analysis-Part 2: Recommended methods for sensory evaluation. 2009.

20) S. L. Drake, P. D. Geraed, M. A. Drake; Consumer preferences for mild cheddae cheese flavors. I. Food Sci., 73, 449455, (2008)

21) M. Hori, K. Horiguti, S. Sawayama; "Sensory evaluation of commercial yogurt” (in Japanese). JJSE, 14, 40-45, (2010).

22) S. Fujikawa, S. Kawamura; "Taste evaluation of drinking milk by physicochemical properties and sensory determinations" (in Japanese). Journal of JSAM, 75, 37-44, (2013).

23) L. Lemieux, R. Puchades, R. E. Simardre; Size-exclusion HPLC separation of bitter and astringent fractions from cheddar cheese made with added lactobacillus strains to accelerate ripening. J. Food Sci., 54, 234-1237, (1989).

24) L. Lemieux, R. E. Simard; Astringency, a textural defect in dairy products. Lait., 74, 217-240, (1994).

25) T. K. Singh, M. A. Drake, K. R. Cadwallader; Flavor of cheddar cheese: a chemical and sensory perspective. Compr. Rev.
Food Sci. Food Saf., 2, 166-189, (2003).

26) M. E. Morgan; The chemistry of some microbially induced flavor defects in milk and dairy foods. Biotechnol. Bioeng., 18, 953-965, (1976).

27) F. W. Bodyfelt, J. Tobias, G. M. Trout; The sensory evaluation of dairy products. New York, NY ., 339-342, 1988.

28) W. J. Dunn, S. Wold, U. Edlund, S. Hellberg, J. Gasteiger; Multivariate structure-activity relationships between data from a battery of biological tests and an ensemble of structure descriptors: The PLS method. Quant. Struct. Relationships, 3, 131-137, (1984).

29) I.-G. Chong, C.-H. Jun; Performance of some variable selection methods when multicollinearity is present. Chemom. Intell. Lab. Syst., 78, 103-112, (2005).

30) C.-H. Jun; Use of partial least squares regression for variable selection and quality prediction. in 2009 International Conference on Computers \& Industrial Engineering, 13021307, 2009.

要旨

チェダーチーズの粘弾性計測パラメータと官能評価 スコアの相互関係解析に基づいて，高精度で官能評価 スコアを予測する機器試験法の組み合わせを選択する 方法および PLS 解析法と ANN モデリングを併用して 品質と嗜好度を評価するモデルを提唱した。供試サン プルとしてチェダーチーズ 10 品を選定し，破断，クリー プおよびテクスチャの 3 試験法により粘弾性パラメー タを取得した。他方，食感属性用語 10 語を含む官能評 価用語 38 語を選定し，それらを使用した分析型官能評 価と消費者嗜好度調査を実施して官能評価スコアおよ び嗜好度を得た。供試サンプルの 2 バイト咀嚼による 荷重経時変化曲線に基づいて食感と粘弾性計測特性と の時系列的対応関係を解釈し，口腔内で感じる食感変 化を粘弾性試験法の組み合わせによって良好に予測す る方法を提示した。この方法では PLS 回帰分析の予測 精度の比較によって食感評価スコアと良好な対応を示 す粘弾性試験法の組み合わせを特定した。さらには, それぞれの試験法の組み合わせで得られた粘弾性パラ メータを適用して食感評価スコアおよび嗜好度を予測 する ANN モデルを構築した．この方法の導入によって， 食感評価スコアの予測に最も寄与する粘弾性試験法の 組み合わせを選択して ANN モデルを操作することが可 能となった。 